\title{
USE OF TAGUCHI METHODS FOR HIERARCHY OF INFLUENCE FACTORS IN THE APPLICATION OF CARBONITRATION IN A FLUIDIZED BED STEEL FOR 41Cr4 STEEL
}

\author{
Nelu CAZACU \\ "Dunarea de Jos" University of Galati, Romania \\ e-mail: nelu.cazacu@ugal.ro
}

\begin{abstract}
The work is based on carbonitriding in a fluidized layer with methane and ammonia gas applied to $41 \mathrm{Cr} 4$ steel samples. To achieve the best possible results, other factors must be taken into account, than those specific to carbonitring. It was necessary to use a partially factorial working procedure due to the increase in the number of factors. An A18 matrix has been used, with 18 lines of experiments in which three levels have been modified for 6 factors. The objective function was fixed at the final hardness after carbonitriding, hardening and tempering. The carbonitriding was performed in fluidized bed with granular solid ground and sorted to 0.1- to 0.16mm, and brought to fluidization with a mixture of methane and ammonia. The hardening has been done directly after carbonitriding in the fluidized bed. The experiments have been performed according to Taguchi Methods and the results indicate an optimal regime and the influence of the factors considered on the hardness after the thermo-chemical treatment and the thermal treatment. Metallographic analysis has been performed on the carbonitrided layer.
\end{abstract}

KEYWORDS: fluidized bed, Taguchi method (T M), 41Cr4, carbonitriding

\section{Introduction}

The fluidized bed is used as a medium for heat treatments of small bulk parts providing high heat transfer and mass capacities. High heat and mass transfer coefficients lead to balancing treatment costs by drastically reducing the process time. The limitations brought by the fluidization are related to the dimensions of the fluidization spaces and implicitly to the dimensions of the parts, and last but not least to the treatment costs. The quality indicators are influenced by the positioning of the active surfaces in relation to the axis of the fluidization chamber [1].

$41 \mathrm{Cr} 4$ steel is an alloy steel for improvement but to which subsequent surface treatments can be applied. Usually this steel is intended for: - machine parts and heat-treated parts with a guaranteed hardening depth according to the brand's quality curve such as: smooth shafts, grooved shafts, crankshafts, bandages.

The chemical composition of $41 \mathrm{Cr} 4$ steel is: $\mathrm{C}=$ $(0.36 \div 0.44) \% ; \mathrm{P}=\max 0.035 \% ; \mathrm{Mn}=(0.50 \div 0.80) \%$; $\mathrm{S}=\max 0.035 \%, \quad \mathrm{Si}=(0.17 \div 0.37) \% ; \mathrm{Cr}=$ $(0.8 \div 1.1) \%$.
Also, some residual elements are accepted: max. $0.3 \% \mathrm{Ni}$; max. 0.3\% Cu; max. 0.02\% Ti (Table 1).

Forms of delivery: hot rolled flat products; semifinished products for forging; rolled and drawn wires

Recommended heat treatments:

Soaking annealing consisting of austenitization at $\mathrm{T}=(680 \div 720){ }^{\circ} \mathrm{C}$ followed by oven cooling.

Normalization for which austenitization is performed at $\mathrm{T}=(840 \div 870){ }^{\circ} \mathrm{C}$ followed by cooling in still air.

The most important treatment is martensitic volumetric hardening, which is done after austenitization at $\mathrm{T}=(820 \div 850){ }^{\circ} \mathrm{C}$ followed by cooling in water and with subsequent cooling in water or oil.

Afterwards, surface treatments can be made for nitriding, nitrocarburizing or local hardening by laser hardening.

Carbonitriding is considered the most widely used thermo-chemical treatment (surface heat treatment with diffusion) [1]. The presence of active nitrogen in the decomposition of ammonia makes it possible to increase the chemical activity of carbon at lower heating temperatures, which leads to a decrease in costs without affecting the structure/surface 
properties complex. Carbonitriding leads to a controlled increase in surface carbon and it may lead to changes in surface properties relative to the base material if surface treatment is properly continued. The paper studies the situation in which, in order to increase the hardenability of the surface layer, a surface treatment is made prior to the hardening and recovery mentioned above. In this case, the fluidized bed is used as a carbonitriding medium, which brings new process control factors [2, 3]. The experimental procedure used is based on TM with orthogonal array [2] to determine the share of influencing factors on the overall heat treatment applied to $41 \mathrm{Cr} 4$ steel.

\section{Experimental conditions}

Samples of $41 \mathrm{Cr} 4$ steel have been used for experiments. The chemical composition is shown in Table 1 and it reveals the class of steels to which it belongs, namely steels with $1 \% \mathrm{Cr}$. The steel is intended for improvement, but the application prior to the improvement of a carbonitriding treatment versus the increase of the calcification of the surface layer and thus, of the complex of superior surface properties, can be obtained [2-4].

It is a mass and energy transfer medium that can be very active which leads to high values of mass and energy transfer coefficients. For example, for an ITTSF furnace (5) with a fluidized layer with a diameter of $0.35 \mathrm{~m}$ and initial $\mathrm{H} / \mathrm{D}$ ratio $=1.1$ the temperature of the centre of a spherical sample with a diameter of $0.05 \mathrm{~m}$ introduced in the incubator with the temperature of $850{ }^{\circ} \mathrm{C}$, shows that by increasing the fluidization speed $\mathrm{c}=$ it occurs a significant decrease in equalization time to approx. $100 \mathrm{~s}$ of the sample temperature. For the same oven without a fluidized bed that has been transformed into an electric oven with a retort, the equalization time of the sample is $400 \mathrm{~s}$. It is also found that the fluidization speed influences, within certain limits, the heat transfer process (Fig. 1).

Similarly, fluidization speed also influences the mass transfer coefficient, which becomes important in surface diffusion treatments such as carbonitriding (Table 2) [1].

Table 1. Chemical composition of 41Cr4 steel samples

\begin{tabular}{cccccccccc}
\hline $\mathrm{C}$ & $\mathrm{Mn}$ & $\mathrm{Si}$ & $\mathrm{P}$ & $\mathrm{S}$ & $\mathrm{Cr}$ & $\mathrm{Ni}$ & $\mathrm{Cu}$ & $\mathrm{Mo}$ & $\mathrm{Al}$ \\
\hline 0.4 & 0.6 & 0.3 & 0.019 & 0.02 & 0.97 & 0.2 & 0.27 & 0.065 & 0.015 \\
\hline
\end{tabular}

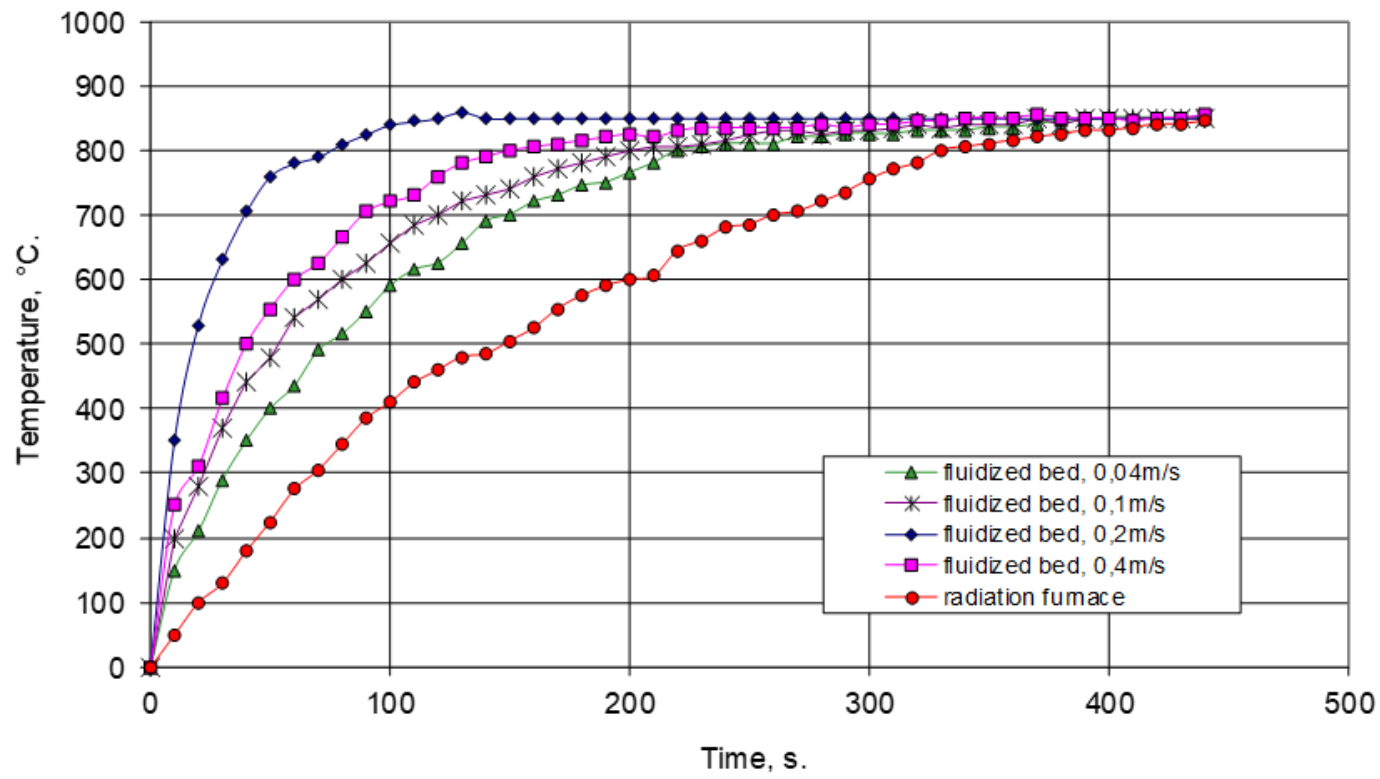

Fig. 1. Temperature variation of a stainless-steel spherical sample (2 inches) when introduced at an $85^{\circ} \mathrm{C}$ in an electric furnace at and in a fluidized bed furnace (ITTSF (5), for different fluidization speed) [1] 
Table 2. Fluidisation speed (levels for experiments)

\begin{tabular}{ccccccc}
\hline no. & & & debit & & $\begin{array}{c}\text { under } \\
\text { mesh } \\
\text { speed }\end{array}$ & $\begin{array}{c}\text { fluidisa- } \\
\text { tion } \\
\text { speed }\end{array}$ \\
\hline 1 & 394 & 6.56 & 0.394 & 0.015 & 0.029 \\
2 & 544 & 9.07 & 0.544 & 0.021 & 0.040 \\
3 & 694 & 11.57 & 0.694 & 0.027 & 0.051 \\
\hline
\end{tabular}

Table 3. Other factors that characterize used fluidized bed

\begin{tabular}{lccc}
\hline \multicolumn{1}{c}{ parameter } & symbol & value & $\mathrm{m} . \mathrm{u}$. \\
\hline the average diameter of the soli & $\mathrm{d}_{\mathrm{p}}$ & 0.00024 & $\mathrm{~m}$ \\
form factor & $\phi$ & 0.6 & - \\
solid density & $\rho_{\mathrm{p}}$ & 2650 & $\mathrm{~kg} / \mathrm{m}^{3}$ \\
gas density & $\rho_{\mathrm{g}}$ & 1.29 & $\mathrm{~kg} / \mathrm{m}^{3}$ \\
kinematic viscosity & $\eta$ & $1.34 \mathrm{E}-05$ & $\mathrm{~m}^{2} / \mathrm{s}$ \\
gravitational acceleration & $\mathrm{g}$ & 9.81 & $\mathrm{~m} / \mathrm{s}^{2}$ \\
initial height of the bed & $\mathrm{H}$ & 0.1 & $\mathrm{~m}$ \\
Inside diameter of the enclosure & $\mathrm{D}$ & 0.096 & $\mathrm{~m}$ \\
Archimedes' criterion & $\mathrm{Ar}$ & 1550.74 & - \\
initial porosity & $\varepsilon$ & 0.52 & - \\
fluidization speed & $\mathrm{w}$ & 0.000154 & $\mathrm{~m} / \mathrm{s}$ \\
\hline
\end{tabular}

Table 4. Factors considered to have significant influence over experiments

\begin{tabular}{clcc}
\hline No. & \multicolumn{1}{c}{ factors } & $\mathrm{mu}$ & range \\
\hline 1 & carbonitriding temperature & ${ }^{\circ} \mathrm{C}$ & $800 \ldots 900$ \\
2 & carbonitriding time & $\mathrm{S}$ & $60 \ldots 600$ \\
3 & debit & $\mathrm{l} / \mathrm{h}$ & $433,584,734$ \\
4 & tempering temperature & ${ }^{\circ} \mathrm{C}$ & $100 \ldots 250$ \\
5 & tempering time & $\mathrm{min}$ & $5 \ldots 15$ \\
6 & pozition in furnace & - & low, medium, high \\
7 & dimension of granular solid & $\mathrm{m}^{*} 10^{-3}$ & $0,10 \ldots 0,16$ \\
8 & fluidized bed volume & $\mathrm{m}^{3}$ & $\mathrm{ct}$ \\
9 & steel chemical composition & $\%$ & $\mathrm{ct}$. \\
10 & fluidized bed shape rate $\mathrm{D} / \mathrm{H}$ & - & $1 \ldots 1,5$ \\
11 & ammonia rate & $\%$ & $5 \ldots 15$ \\
12 & surface quality & - & small, medium, large \\
\hline
\end{tabular}

\subsection{Experimental matrix}

The multitude of factors influences the process of carbonitriding + hardening + tempering, to which are added the influencing factors of fluidization and carbonitriding in fluidized layer, making the factors in Table 5 to be selected from Tables 4 . Previous experiments [3] for the carbonitriding of $41 \mathrm{Cr} 4$ steel in a fluidized layer with an initial gaseous mixture of methane and ammonia, showed the factors influencing the experiments and their fields of variation Table 4.
According to the procedure known as Taguchi Methods [6-8] when the number of factors is large, it is difficult to perform "full factorial" technological experiments due to increased costs, duration of experiments and their complexity, the use of experimental matrix being recommended. Using an appropriate mathematical model $[6,8]$, a matrix with a small number of experiments can be constructed.

For the proposed experiments we have the orthogonal matrix L18, with 18 lines, which has 8 factors considered and each three values. $3^{8}=6561$ experiments are replaced with 18 experiments. 
Another property that results from the orthogonality of the matrix is that two columns can be omitted (column 1 and column 7) without influencing the result of the experiments, thus obtaining a matrix with 18 lines for 6 factors and each with three levels i.e., $3^{6}=729$ experiments are replaced with 18 experiments.

The results provide the weight of influence of the considered factors and they can be completed with a set of full-factorial experiments on a much smaller number of factors and with smaller domains of variation $[6,8]$.

Orthogonal matrix L18 $[6,8]$ is presented in Table 6. Completing the L18 matrix with the values of the factor levels it will lead to the experiment matrix with 18 lines Table 7. The main difficulty of this experimental matrix is that the transition from one line to another is done by modifying the settings for several factors, which in the "full factorial" type experiment matrix means changing only one factor.

Table 5. Selected factors over experiments

\begin{tabular}{clcccc}
\hline & factors & \multirow{2}{*}{ m.u. } & \multicolumn{3}{c}{ selected levels } \\
\cline { 5 - 6 } & & & 1 & 2 & 3 \\
\hline 1 & carbonitriding temperature & ${ }^{\circ} \mathrm{C}$ & 800 & 850 & 900 \\
2 & carbonitriding time & $\min$ & 1 & 5 & 10 \\
3 & debit & $1 / \mathrm{h}$ & 394 & 544 & 694 \\
4 & tempering temperature & ${ }^{\circ} \mathrm{C}$ & 100 & 150 & 200 \\
5 & tempering time & $\min$ & 5 & 10 & 15 \\
6 & ammonia rate & $\%$ & 5 & 10 & 15 \\
\hline
\end{tabular}

Table 6. Typical orthogonal array L18 for 6 factors and each 3 levels

\begin{tabular}{ccccccccc}
\hline & \multicolumn{7}{c}{ Factori specificati } \\
\cline { 2 - 8 } Experiment & 1 & 2 & 3 & 4 & 5 & 6 & 7 & 8 \\
\cline { 2 - 8 } & $\mathrm{e}$ & $\mathrm{A}$ & $\mathrm{B}$ & $\mathrm{C}$ & $\mathrm{D}$ & $\mathrm{E}$ & $\mathrm{e}$ & $\mathrm{F}$ \\
\hline 1 & 1 & 1 & 1 & 1 & 1 & 1 & 1 & 1 \\
2 & 1 & 1 & 2 & 2 & 2 & 2 & 2 & 2 \\
3 & 1 & 1 & 3 & 3 & 3 & 3 & 3 & 3 \\
4 & 1 & 2 & 1 & 1 & 2 & 2 & 3 & 3 \\
5 & 1 & 2 & 2 & 2 & 3 & 3 & 1 & 1 \\
6 & 1 & 2 & 3 & 3 & 1 & 1 & 2 & 2 \\
\hline 7 & 1 & 3 & 1 & 2 & 1 & 3 & 2 & 3 \\
8 & 1 & 3 & 2 & 3 & 2 & 1 & 3 & 1 \\
9 & 1 & 3 & 3 & 1 & 3 & 2 & 1 & 2 \\
10 & 2 & 1 & 1 & 3 & 3 & 2 & 2 & 1 \\
11 & 2 & 1 & 2 & 1 & 1 & 3 & 3 & 2 \\
12 & 2 & 1 & 3 & 2 & 2 & 1 & 1 & 3 \\
\hline 13 & 2 & 2 & 1 & 2 & 3 & 1 & 3 & 2 \\
14 & 2 & 2 & 2 & 3 & 1 & 2 & 1 & 3 \\
15 & 2 & 2 & 3 & 1 & 2 & 3 & 2 & 1 \\
16 & 2 & 3 & 1 & 3 & 2 & 3 & 1 & 2 \\
17 & 2 & 3 & 2 & 1 & 3 & 1 & 2 & 3 \\
18 & 2 & 3 & 3 & 2 & 1 & 2 & 3 & 1 \\
\hline
\end{tabular}


THE ANNALS OF "DUNAREA DE JOS" UNIVERSITY OF GALATI

FASCICLE IX. METALLURGY AND MATERIALS SCIENCE

No. 3 - 2021, ISSN 2668-4748; e-ISSN 2668-4756

Article DOI: $\underline{\text { https://doi.org/10.35219/mms.2021.3.07 }}$

Table 7. Experimental matrix with 18 lines

\begin{tabular}{|c|c|c|c|c|c|c|}
\hline \multirow{4}{*}{ experiment } & \multicolumn{6}{|c|}{ specified factors } \\
\hline & 1 & 2 & 3 & 4 & 5 & 6 \\
\hline & $\begin{array}{c}\text { carbonitriding } \\
\text { temperature }\end{array}$ & $\begin{array}{c}\text { carbonitriding } \\
\text { time }\end{array}$ & debit & $\begin{array}{c}\text { tempering } \\
\text { temperature }\end{array}$ & $\begin{array}{l}\text { tempering } \\
\text { time }\end{array}$ & ammonia rate \\
\hline & $\mathrm{A}$ & $\mathrm{B}$ & $\mathrm{C}$ & $\mathrm{D}$ & $E$ & $\mathrm{~F}$ \\
\hline m.u. & ${ }^{\circ} \mathrm{C}$ & $\min$ & $\mathrm{l} / \mathrm{h}$ & ${ }^{\circ} \mathrm{C}$ & $\min$ & $\%$ \\
\hline 1 & 800 & 1 & 394 & 100 & 5 & 5 \\
\hline 2 & 800 & 5 & 544 & 150 & 10 & 10 \\
\hline 3 & 800 & 10 & 694 & 200 & 15 & 15 \\
\hline 4 & 850 & 1 & 394 & 150 & 10 & 15 \\
\hline 5 & 850 & 5 & 544 & 200 & 15 & 5 \\
\hline 6 & 850 & 10 & 694 & 100 & 5 & 10 \\
\hline 7 & 900 & 1 & 544 & 100 & 15 & 15 \\
\hline 8 & 900 & 5 & 694 & 150 & 5 & 5 \\
\hline 9 & 900 & 10 & 394 & 200 & 10 & 10 \\
\hline 10 & 800 & 1 & 694 & 200 & 10 & 5 \\
\hline 11 & 800 & 5 & 394 & 100 & 15 & 10 \\
\hline 12 & 800 & 10 & 544 & 150 & 5 & 15 \\
\hline 13 & 850 & 1 & 544 & 200 & 5 & 10 \\
\hline 14 & 850 & 5 & 694 & 100 & 10 & 15 \\
\hline 15 & 850 & 10 & 394 & 150 & 15 & 5 \\
\hline 16 & 900 & 1 & 694 & 150 & 15 & 10 \\
\hline 17 & 900 & 5 & 394 & 200 & 5 & 15 \\
\hline 18 & 900 & 10 & 544 & 100 & 10 & 5 \\
\hline
\end{tabular}

Table 8. Hardness determination for each experiment and target function calculus

\begin{tabular}{|c|c|c|c|c|}
\hline \multirow{2}{*}{ experiment } & \multicolumn{2}{|c|}{ hardness } & \multirow{2}{*}{$\begin{array}{c}\text { average } \\
\text { hardness }\end{array}$} & \multirow{2}{*}{$\begin{array}{c}\text { target } \\
\text { function }\end{array}$} \\
\hline & HV1 & HV2 & & \\
\hline m.u & $\mathrm{kgf} / \mathrm{mm}^{2}$ & $\mathrm{kgf} / \mathrm{mm}^{2}$ & $\mathrm{kgf} / \mathrm{mm}^{2}$ & $\mathrm{~dB}$ \\
\hline 1 & 336 & 341 & 339 & 25.30 \\
\hline 2 & 781 & 857 & 819 & 29.13 \\
\hline 3 & 701 & 655 & 678 & 28.31 \\
\hline 4 & 667 & 667 & 667 & 28.24 \\
\hline 5 & 795 & 857 & 826 & 29.17 \\
\hline 6 & 946 & 1027 & 987 & 29.94 \\
\hline 7 & 825 & 825 & 825 & 29.16 \\
\hline 8 & 781 & 781 & 781 & 28.93 \\
\hline 9 & 810 & 891 & 851 & 29.30 \\
\hline 10 & 494 & 509 & 502 & 27.00 \\
\hline 11 & 874 & 810 & 842 & 29.25 \\
\hline 12 & 857 & 825 & 841 & 29.25 \\
\hline 13 & 713 & 689 & 701 & 28.46 \\
\hline 14 & 825 & 857 & 841 & 29.25 \\
\hline 15 & 891 & 874 & 883 & 29.46 \\
\hline 16 & 752 & 781 & 767 & 28.85 \\
\hline 17 & 726 & 701 & 714 & 28.53 \\
\hline 18 & 739 & 766 & 753 & 28.77 \\
\hline & & & $m=$ & 28.68 \\
\hline
\end{tabular}


THE ANNALS OF "DUNAREA DE JOS" UNIVERSITY OF GALATI

FASCICLE IX. METALLURGY AND MATERIALS SCIENCE

No. 3 - 2021, ISSN 2668-4748; e-ISSN 2668-4756

Article DOI: $\underline{\text { https://doi.org/10.35219/mms.2021.3.07 }}$

Table 9. Calculus for average effect of each level for each factor over experiments

\begin{tabular}{lll}
\hline relation & value \\
\hline $\mathrm{mA} 1=$ & $1 / 6(\mathrm{n} 1+\mathrm{n} 2+\mathrm{n} 3+\mathrm{n} 10+\mathrm{n} 11+\mathrm{n} 12)=$ & 28.04 \\
$\mathrm{~mA} 2=$ & $1 / 6(\mathrm{n} 4+\mathrm{n} 5+\mathrm{n} 6+\mathrm{n} 13+\mathrm{n} 14+\mathrm{n} 15)=$ & 29.09 \\
$\mathrm{~mA} 3=$ & $1 / 6(\mathrm{n} 7+\mathrm{n} 8+\mathrm{n} 9+\mathrm{n} 16+\mathrm{n} 17+\mathrm{n} 18)=$ & 28.92 \\
$\mathrm{mB} 1=$ & $1 / 6(\mathrm{n} 1+\mathrm{n} 4+\mathrm{n} 7+\mathrm{n} 10+\mathrm{n} 13+\mathrm{n} 16)=$ & 27.83 \\
$\mathrm{mB} 2=$ & $1 / 6(\mathrm{n} 2+\mathrm{n} 5+\mathrm{n} 8+\mathrm{n} 11+\mathrm{n} 14+\mathrm{n} 17)=$ & 29.04 \\
$\mathrm{mB} 3=$ & $1 / 6(\mathrm{n} 3+\mathrm{n} 6+\mathrm{n} 9+\mathrm{n} 12+\mathrm{n} 15+\mathrm{n} 18)=$ & 29.17 \\
\hline $\mathrm{mC} 1=$ & $1 / 6(\mathrm{n} 1+\mathrm{n} 4+\mathrm{n} 9+\mathrm{n} 11+\mathrm{n} 15+\mathrm{n} 17)=$ & 28.35 \\
$\mathrm{mC} 2=$ & $1 / 6(\mathrm{n} 2+\mathrm{n} 5+\mathrm{n} 7+\mathrm{n} 12+\mathrm{n} 13+\mathrm{n} 18)=$ & 28.99 \\
$\mathrm{mC} 3=$ & $1 / 6(\mathrm{n} 3+\mathrm{n} 6+\mathrm{n} 8+\mathrm{n} 10+\mathrm{n} 14+\mathrm{n} 16)=$ & 28.71 \\
$\mathrm{mD} 1=$ & $1 / 6(\mathrm{n} 1+\mathrm{n} 6+\mathrm{n} 7+\mathrm{n} 11+\mathrm{n} 14+\mathrm{n} 18)=$ & 28.61 \\
$\mathrm{mD} 2=$ & $1 / 6(\mathrm{n} 2+\mathrm{n} 4+\mathrm{n} 8+\mathrm{n} 12+\mathrm{n} 15+\mathrm{n} 16)=$ & 28.98 \\
$\mathrm{mD} 3=$ & $1 / 6(\mathrm{n} 3+\mathrm{n} 5+\mathrm{n} 9+\mathrm{n} 10+\mathrm{n} 13+\mathrm{n} 17)=$ & 28.46 \\
\hline $\mathrm{mE} 1=$ & $1 / 6(\mathrm{n} 1+\mathrm{n} 6+\mathrm{n} 8+\mathrm{n} 12+\mathrm{n} 13+\mathrm{n} 17)=$ & 28.40 \\
$\mathrm{mE} 2=$ & $1 / 6(\mathrm{n} 2+\mathrm{n} 4+\mathrm{n} 9+\mathrm{n} 10+\mathrm{n} 14+\mathrm{n} 18)=$ & 28.61 \\
$\mathrm{mE} 3=$ & $1 / 6(\mathrm{n} 3+\mathrm{n} 5+\mathrm{n} 7+\mathrm{n} 11+\mathrm{n} 15+\mathrm{n} 16)=$ & 29.03 \\
$\mathrm{mF} 1=$ & $1 / 6(\mathrm{n} 1+\mathrm{n} 5+\mathrm{n} 8+\mathrm{n} 10+\mathrm{n} 15+\mathrm{n} 18)=$ & 28.10 \\
$\mathrm{mF} 2=$ & $1 / 6(\mathrm{n} 2+\mathrm{n} 6+\mathrm{n} 9+\mathrm{n} 11+\mathrm{n} 13+\mathrm{n} 16)=$ & 29.15 \\
$\mathrm{mF} 3=$ & $1 / 6(\mathrm{n} 3+\mathrm{n} 4+\mathrm{n} 7+\mathrm{n} 12+\mathrm{n} 14+\mathrm{n} 17)=$ & 28.79 \\
\hline $\mathrm{m}=$ & 28.68
\end{tabular}

Table 10. Average effect of each level of each factor

\begin{tabular}{llrrrr}
\hline & & \multicolumn{3}{c}{ factors } & \multicolumn{3}{c}{ levels } \\
\cline { 3 - 6 } & & m.u. & 1 & 2 & 3 \\
\hline A & carbonitriding temperature & $\mathrm{dB}$ & 28.04 & 29.09 & 28.92 \\
$\mathrm{~B}$ & carbonitriding time & $\mathrm{dB}$ & 27.83 & 29.04 & 29.17 \\
$\mathrm{C}$ & debit & $\mathrm{dB}$ & 28.35 & 28.99 & 28.71 \\
$\mathrm{D}$ & tempering temperature & $\mathrm{dB}$ & 28.61 & 28.98 & 28.46 \\
$\mathrm{E}$ & tempering time & $\mathrm{dB}$ & 28.40 & 28.61 & 29.03 \\
$\mathrm{~F}$ & ammonia rate & $\mathrm{dB}$ & 28.10 & 29.15 & 28.79 \\
\hline & & & average & $\mathrm{m}=$ & 28.68
\end{tabular}

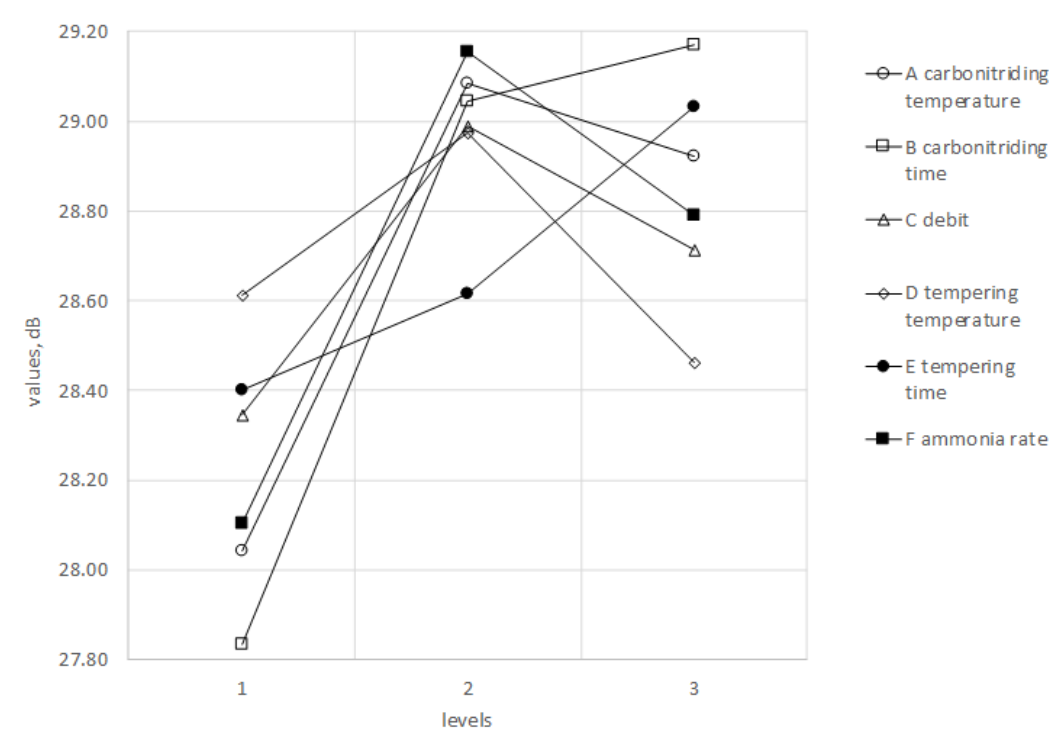

Fig. 2. Graphical representation for average effect of each level of each factor 


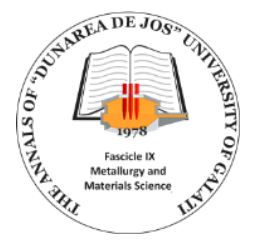

THE ANNALS OF "DUNAREA DE JOS" UNIVERSITY OF GALATI

FASCICLE IX. METALLURGY AND MATERIALS SCIENCE

No. 3 - 2021, ISSN 2668-4748; e-ISSN 2668-4756

Article DOI: https://doi.org/10.35219/mms.2021.3.07

Table 11. ANOVA Analysis

\begin{tabular}{|c|c|c|c|}
\hline & factor & SSDTF & $\begin{array}{c}\text { weight of } \\
\text { factor }\end{array}$ \\
\hline & m.u. & $(\mathrm{dB})^{2}$ & $\%$ \\
\hline$A$ & carbonitriding temperature & 3.79 & 22.06 \\
\hline $\mathrm{B}$ & carbonitriding time & 6.53 & 37.98 \\
\hline C & debit & 1.25 & 7.27 \\
\hline $\mathrm{D}$ & tempering temperature & 0.84 & 4.86 \\
\hline$E$ & tempering time & 1.25 & 7.25 \\
\hline $\mathrm{F}$ & ammonia rate & 3.53 & 20.57 \\
\hline
\end{tabular}

\section{Experiments}

The experiments have been performed following the experimental matrix from Table 7. After completing the 18 experiments on steel sample cabs thus treated, hardness measurements were made on the flat surface, far from the edges (Table 8). For each experiment, the objective function was calculated with the relationship specific to the dependence "the greater is the better" (it is desired to achieve the highest hardness):

$$
n=10 \log (H V m)
$$

The average objective function was calculated for all 18 experiments (Table 8). An important step in the procedure is to calculate the average effect of the level of each factor for all 18 levels (6 factors x3 levels). This is shown in Table 9. It should be noted that the properties of orthogonal matrices also include the frequency of identical occurrence in the matrix for each level of each factor, which means that simplifications of the mathematical model do not influence the achievement of the technological objective by more than a few percent $[6,8]$.

The reorganisation of the values of the mean effect of each factor as in Table 10, allows an intuitive graphical representation (Fig. 2). This graphical representation shows how each factor influences the selected range of variation, respectively the allure of the influence (linear ascending, linear decreasing, with maximum, with minimum, without influence, etc.).

\section{Results and discussion}

The metallographic analysis of the surface layers after carbonitriding is shown from Fig. 5 to Fig. 20.

The microstructures show the combined influence of factors $\mathrm{A}, \mathrm{B}, \mathrm{C}$ and $\mathrm{F}$ that influence the carbonitriding process in the fluidized layer. An analysis of the micrographs shows that:

- for carbonitriding temperatures of $800{ }^{\circ} \mathrm{C}$ (experiments 1, 2, 3, 10, 11 and 12;

- for carbonitriding temperatures of $850{ }^{\circ} \mathrm{C}$ experiments $4,5,6,13,14$ and 15 ;

- for carbonitriding temperatures of $900{ }^{\circ} \mathrm{C}$ experiments 7, 8, 9, 16, 17 and 18 .

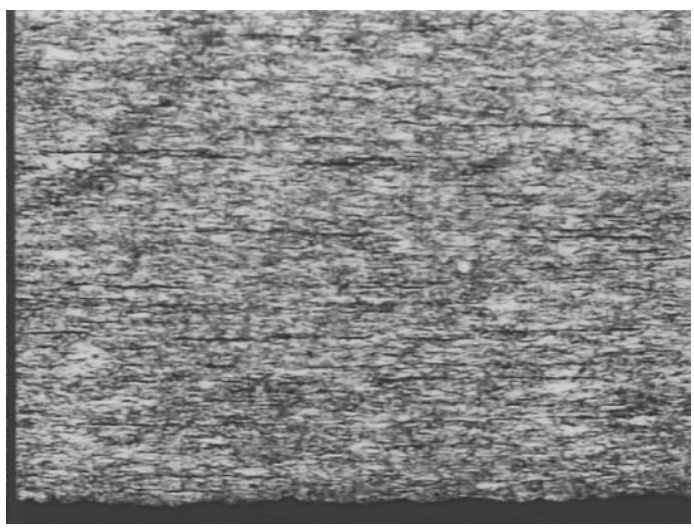

Fig. 3. Heat and thermochemical treatment according to regime 1 (magnification 50x, attack: nital 2\%)

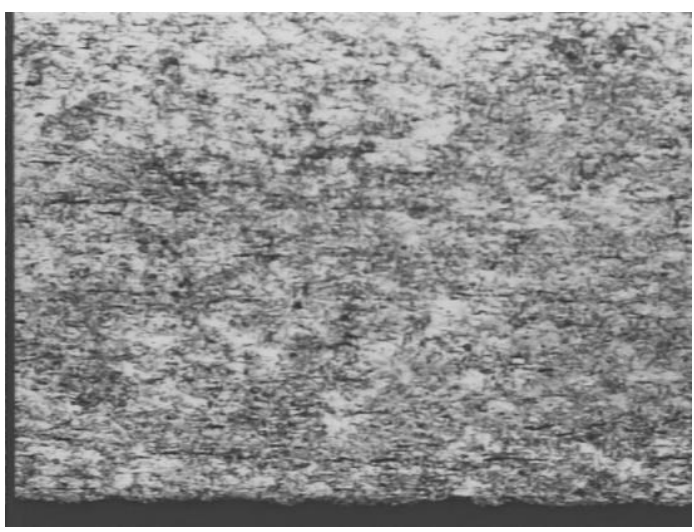

Fig. 4. Heat and thermochemical treatment according to regime 2 (magnification 50x, attack: nital 2\%) 
No. 3 - 2021, ISSN 2668-4748; e-ISSN 2668-4756

Article DOI: https://doi.org/10.35219/mms.2021.3.07

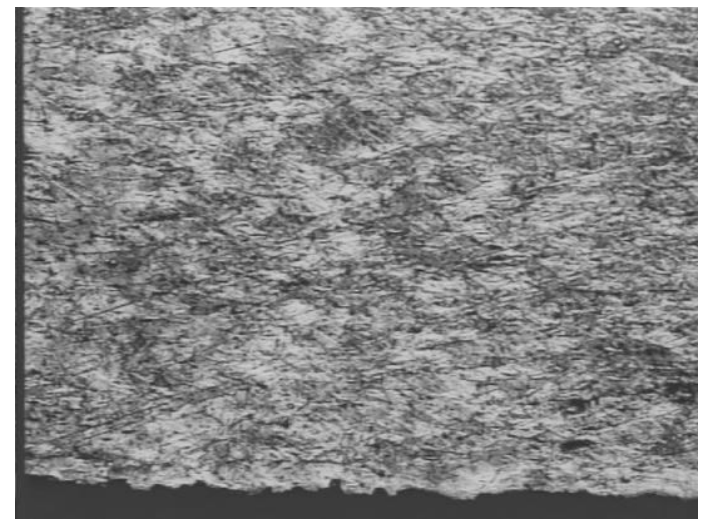

Fig. 5. Heat and thermochemical treatment according to regime 3 (magnification 50x, attack: nital 2\%)

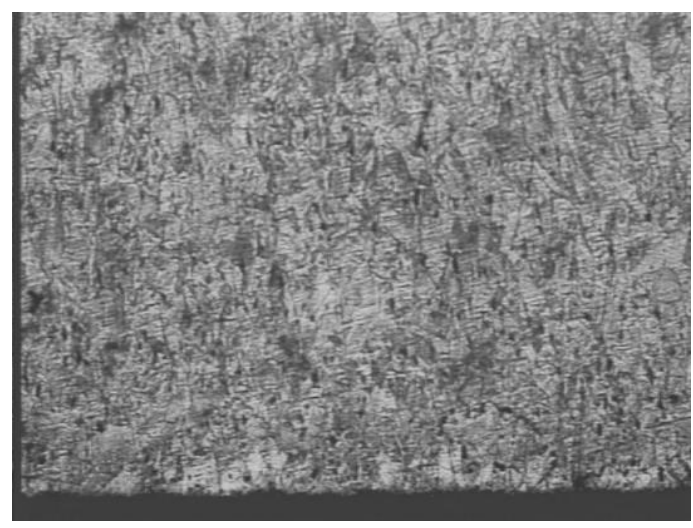

Fig. 6. Heat and thermochemical treatment according to regime 4 (magnification 50x, attack: nital 2\%)

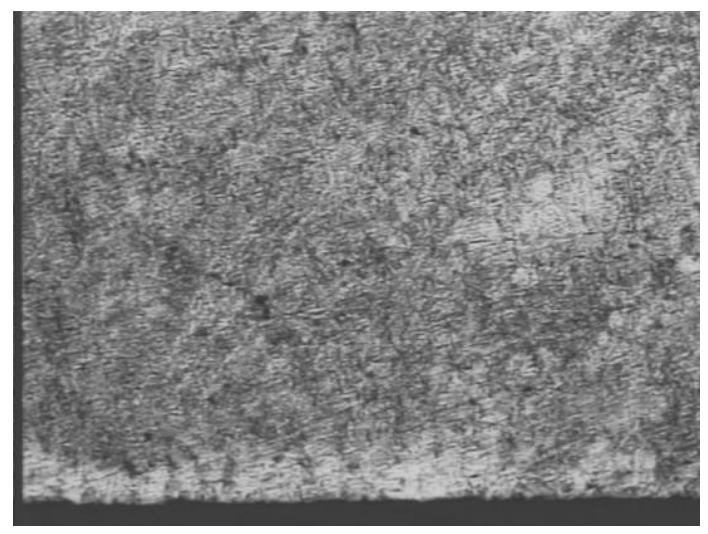

Fig. 7. Heat and thermochemical treatment according to regime 5 (magnification 50x, attack: nital 2\%)

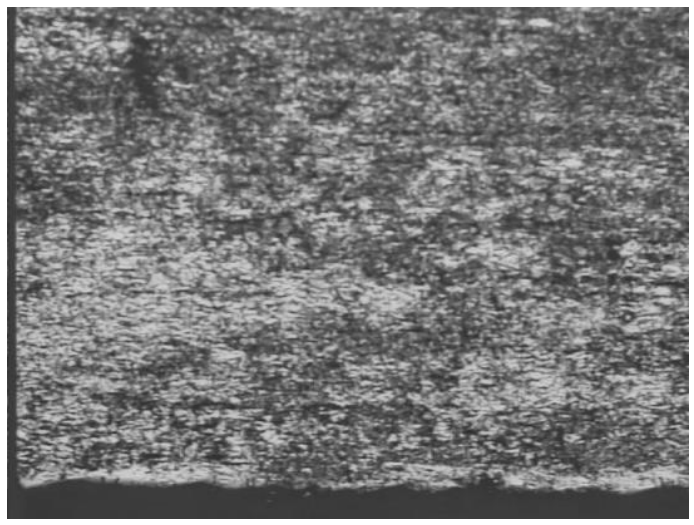

Fig. 8. Heat and thermochemical treatment according to regime 6 (magnification 50x, attack: nital 2\%)

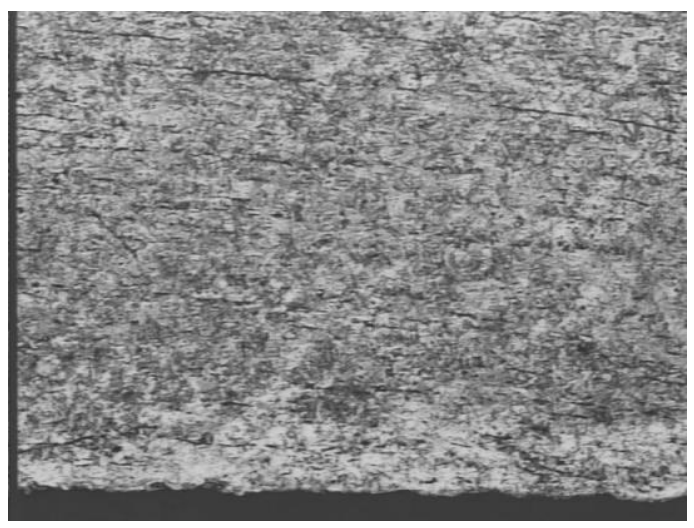

Fig. 9. Heat and thermochemical treatment according to regime 7 (magnification 50x, attack: nital 2\%)

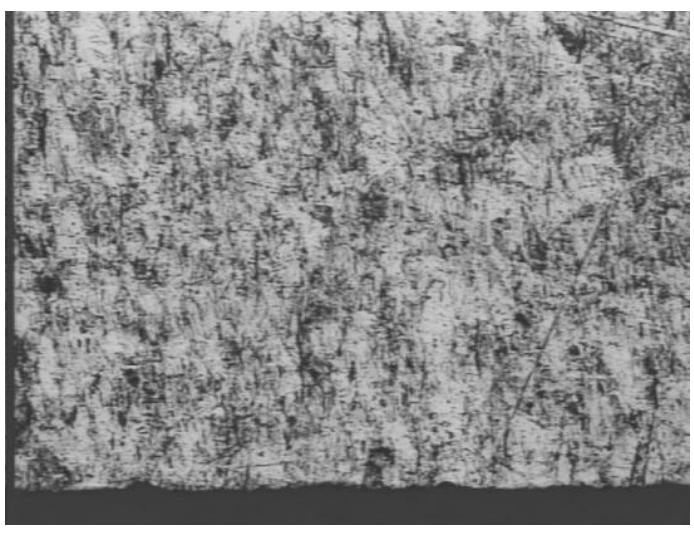

Fig. 10. Heat and thermochemical treatment according to regime 8 (magnification 50x, attack: nital 2\%) 


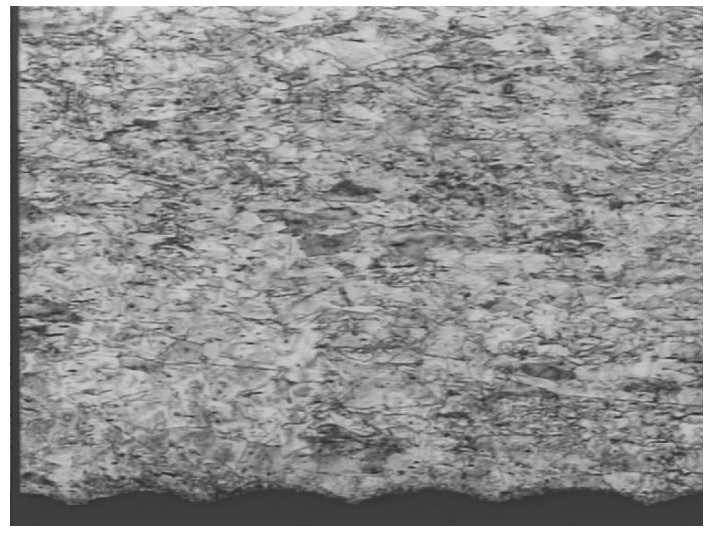

Fig. 11. Heat and thermochemical treatment according to regime 9 (magnification 50x, attack: nital 2\%)

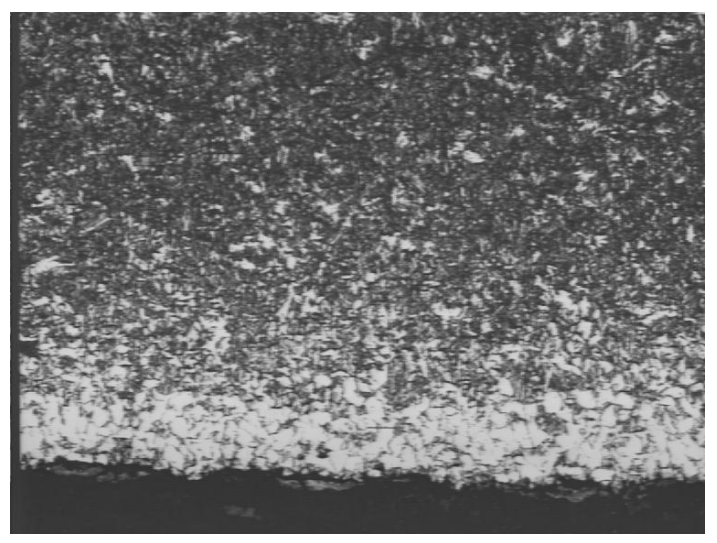

Fig. 12. Heat and thermochemical treatment according to regime 10 (100x magnification, attack: nital 2\%)

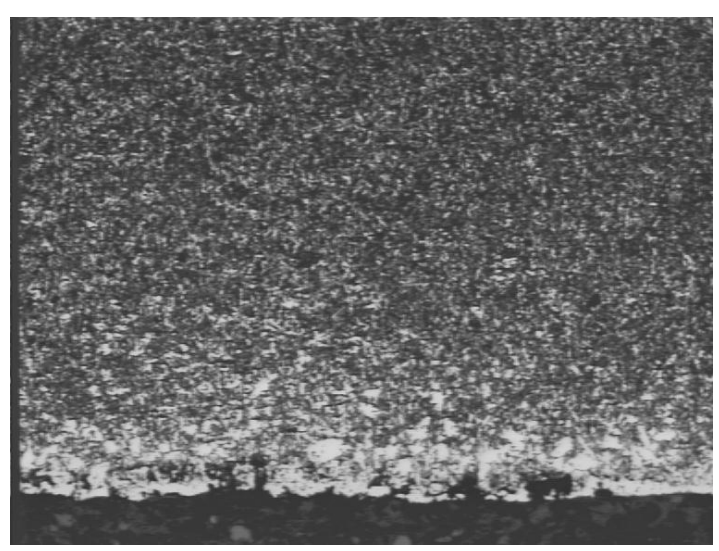

Fig. 13. Heat and thermochemical treatment according to regime 11 (magnification 100x, attack: nital 2\%)

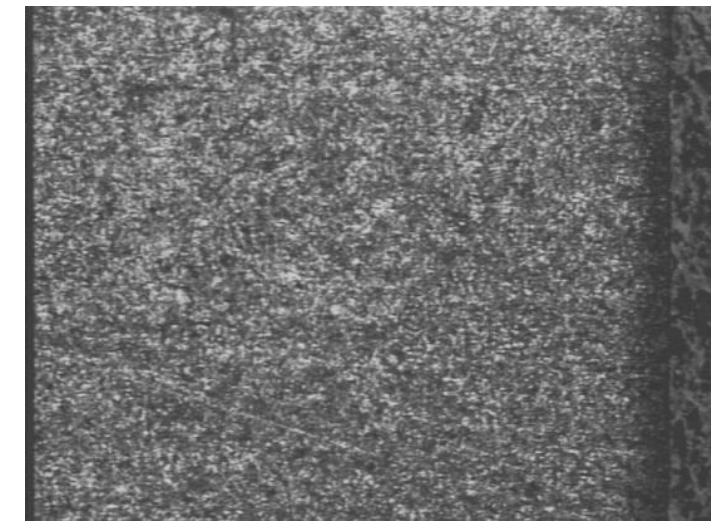

Fig. 14. Heat and thermochemical treatment according to regime 12 (magnification 50x, attack: nital 2\%)

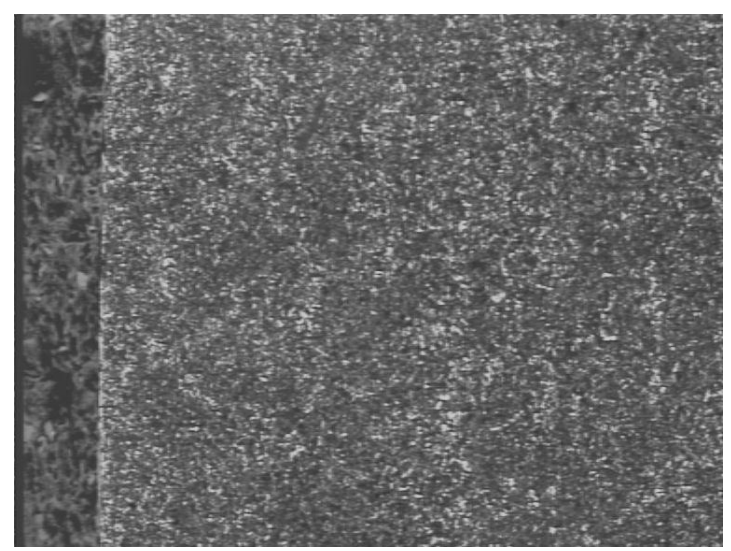

Fig. 15. Heat and thermochemical treatment according to regime 13 (100x magnification, attack: nital 2\%)

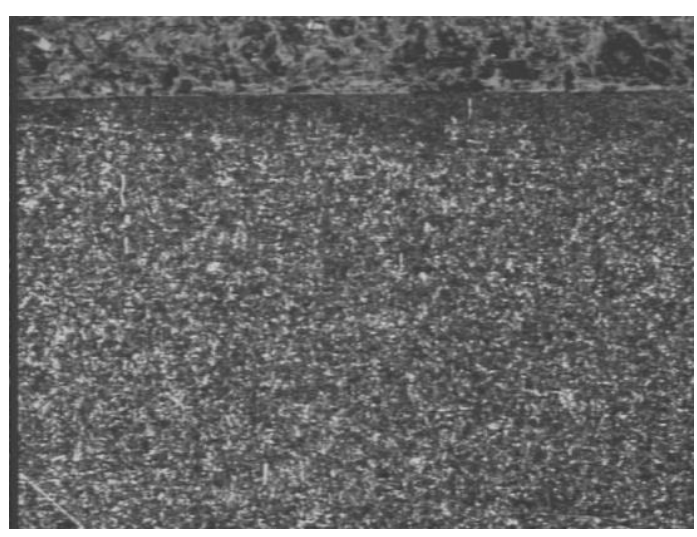

Fig. 16. Heat and thermochemical treatment according to regime 14 (100x magnification, attack: nital 2\%) 


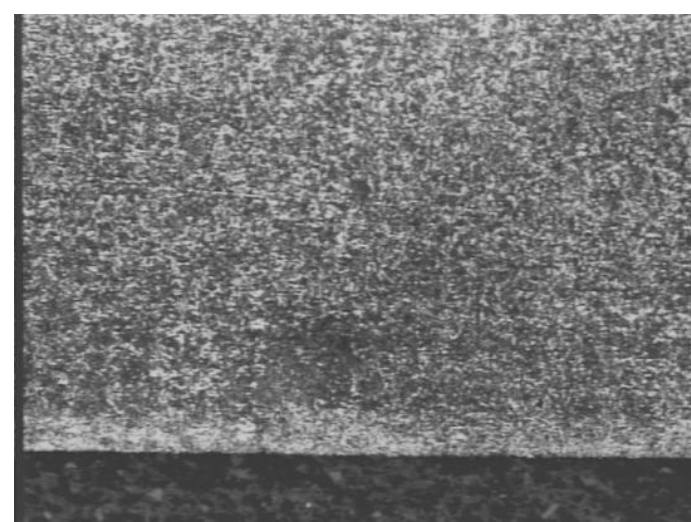

Fig. 17. Heat and thermochemical treatment according to regime 15 (magnification 100x, attack: nital 2\%)

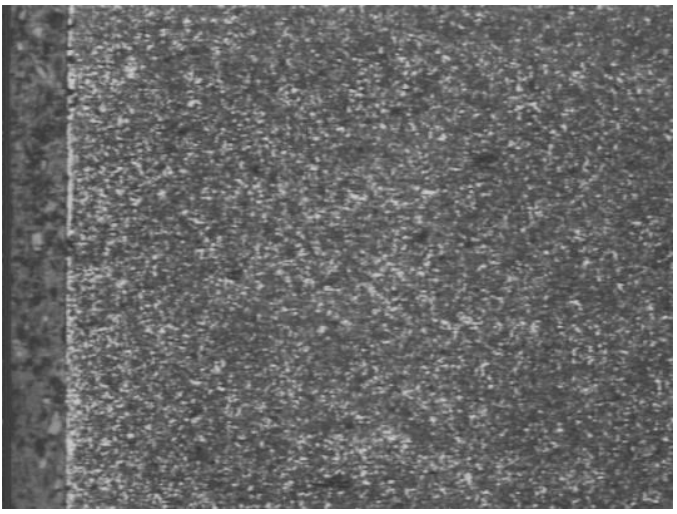

Fig. 18. Heat and thermochemical treatment according to regime 16 (magnification 100x, attack: nital 2\%)

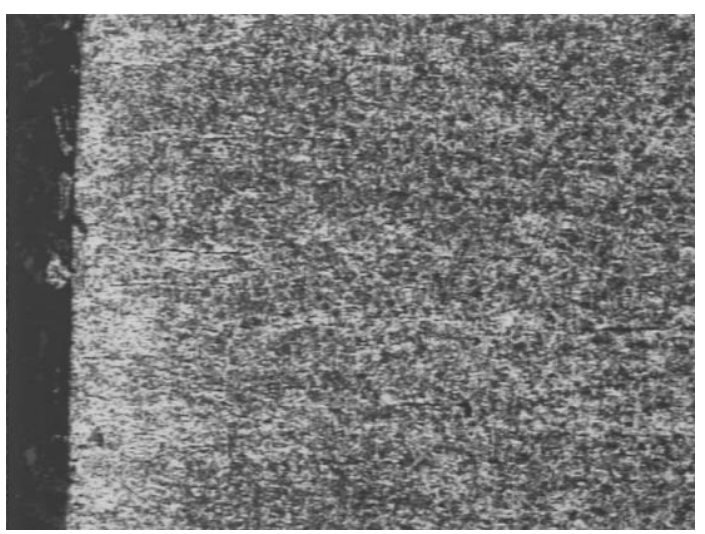

Fig. 19. Heat and thermochemical treatment according to regime 17 (magnification 100x, attack: nital 2\%)

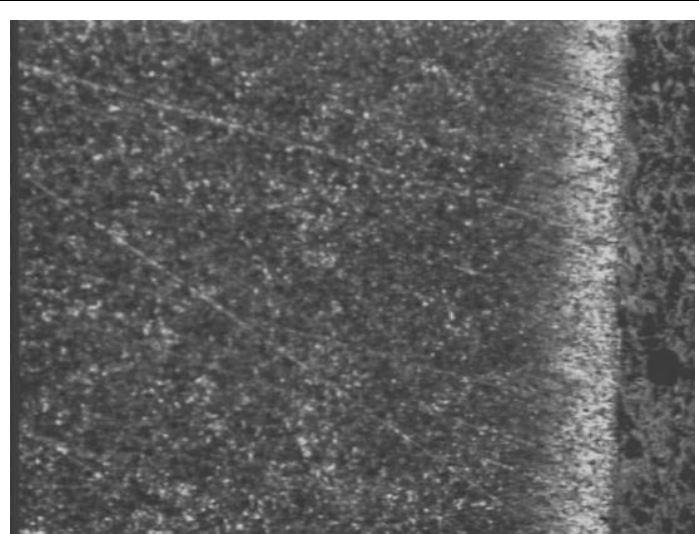

Fig. 20. Heat and thermochemical treatment according to regime 18 (100x magnification, attack: nital 2\%)

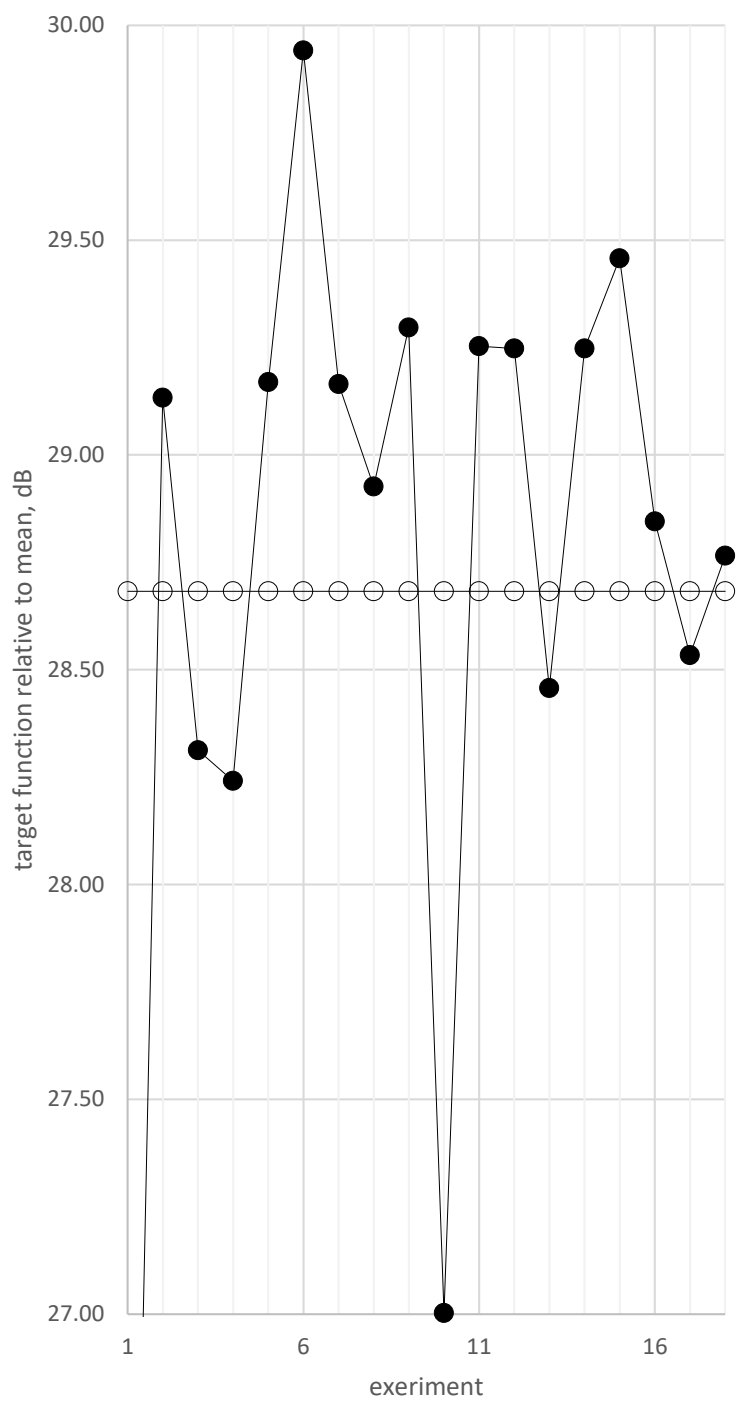

Fig. 21. Target function variations over experiments and mean 


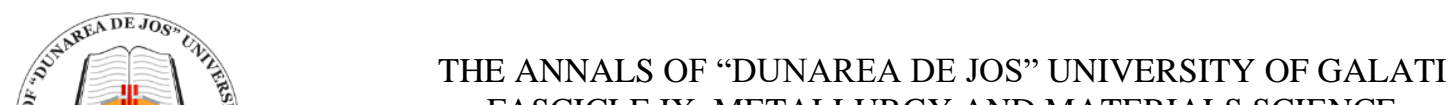

FASCICLE IX. METALLURGY AND MATERIALS SCIENCE

No. 3 - 2021, ISSN 2668-4748; e-ISSN 2668-4756

Article DOI: https://doi.org/10.35219/mms.2021.3.07

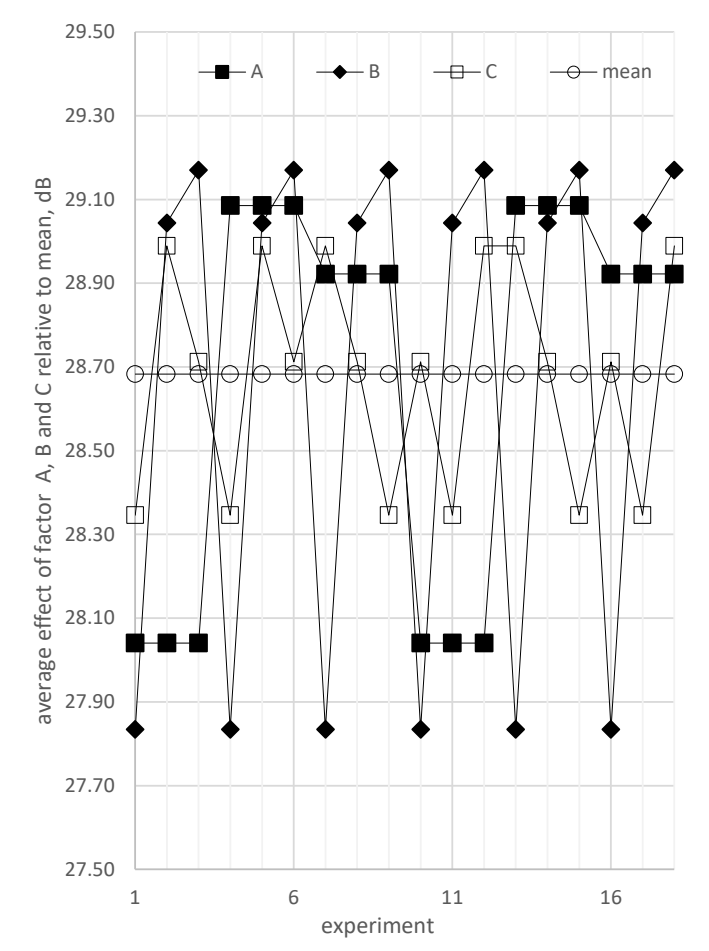

Fig. 22. Average effect of factor $A, B$ and $C$ over experiments relative to mean

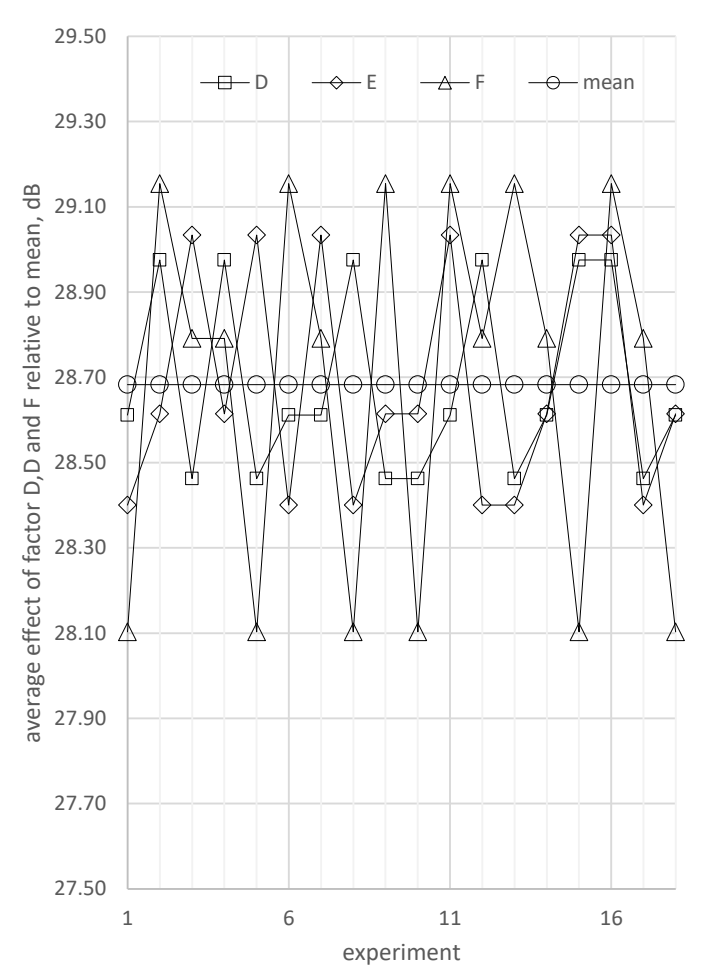

Fig. 23. Average effect of factor $E, F$ and $G$ over experiments relative to mean

Table 13. Optimal setting for each level of each factor

\begin{tabular}{|c|c|c|c|c|c|}
\hline \multirow{2}{*}{\multicolumn{2}{|c|}{ factors }} & \multicolumn{4}{|c|}{ levels } \\
\hline & & m.u. & 1 & 2 & 3 \\
\hline$A$ & carbonitriding temperature & $\mathrm{dB}$ & & 29.09 & \\
\hline B & carbonitriding time & $\mathrm{dB}$ & & & 29.17 \\
\hline $\mathrm{C}$ & debit & $\mathrm{dB}$ & & 28.99 & \\
\hline $\mathrm{D}$ & tempering temperature & $\mathrm{dB}$ & & 28.98 & \\
\hline$E$ & tempering time & $\mathrm{dB}$ & & & 29.03 \\
\hline $\mathrm{F}$ & ammonia rate & $\mathrm{dB}$ & & 29.15 & \\
\hline
\end{tabular}

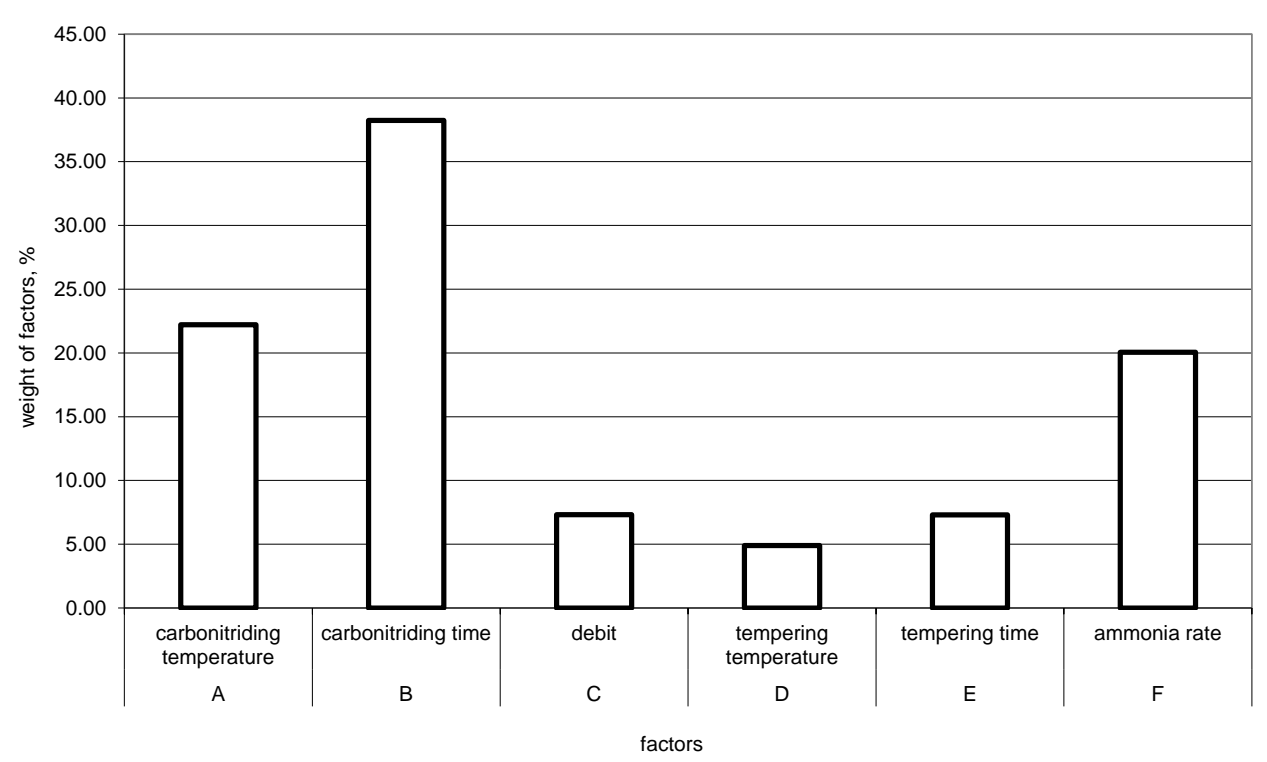

Fig. 24. Weight of factors over experiments 


\section{Conclusions}

The carbonitride layer at high temperatures has a structure similar to the carburized layer (microstructures made before the final hardening) (Fig. 5-20) nitrogen increases the diffusion coefficient of carbon simultaneously with the decrease of the treatment temperature.

Carbonitriding temperatures allow a direct hardening from that temperature, with the advantage of the open chamber used for fluidization.

The mathematical experimentation procedure in orthogonal matrix with its afferent mathematical model offers the different importance of the factors on the experiment, the character of the influence (linear, logarithmic, with maximum / minimum) (Fig. 2.

The microstructures confirm the realization of the thermal and thermochemical treatment processes.

The highest hardness is obtained at temperatures of $850{ }^{\circ} \mathrm{C}$ and a holding time of $10 \mathrm{~min}$ (regime 6) (Table 7, Fig. 8). The lowest hardness has been obtained at temperatures of $800{ }^{\circ} \mathrm{C}$ and a holding time of $1 \mathrm{~min}$ (Table 7, Fig. 3). The influence of temperature and time on carbonitriding is most obvious and is in line with recognized technologies $[9,10]$

The greatest influence on a carburized layer has carbonitriding temperatures, carbonitriding time and the proportion of ammonia. These factors can be considered centroid factors, for which the measurement accuracy is significantly increased.

The least influence on the carburized layer has the inlet gas flow, tempering temperature and return time (Fig. 22).

Experiments show once again that the use of fluidized layers in heat and thermochemical treatments reduces the duration of treatments directly (through specific heat and mass transfer phenomena) and indirectly by reducing loading / unloading times due to working with the enclosure open (Table 7).

\section{References}

[1]. ***, ASM Handbook. Heat Treating, vol. 4, s.1., ASM International, ISBN 0-87170-379-3, 1991.

[2]. Dobrovici Sorin, Bâclea Adolf, Weight Factors over Carbonitriding in Fluidized Bed for 40Cr10 Steel, The Annals of "Dunarea de Jos" University of Galati, Fascicle IX, Metallurgy and Materials Science, p. 70-74, ISSN 1453-083X, 2002.

[3]. Dobrovici Sorin, Cazacu Nelu, Some Aspects of 40Cr10 Steel Behavior on Fluidized Bed Carbonitriding, The Annals of "Dunarea de Jos" University of Galati, Fascicle IX, Metallurgy and Materials Science, p. 17-22, ISSN 1453-083X, 1999.

[4]. Bâclea Adolf, et al., Surface Hardening of 40Cr10 Steel After Short Time Nitriding in Fluidized bed, The Annals of "Dunarea de Jos" University of Galati, Fascicle IX, Metallurgy and Materials Science, vol. 2, p. 40-44, ISSN 1453-083X, 2006.

[5]. ***, ITTSF paper.

[6]. Taguchi G., Introduction to quality engineering into products and processes, s.1.: Asian productivity organization, 1986.

[7]. Logothetis N., Wynn H. P., Quality through design, Oxford: Clarendon Press, ISBN 019859395 3, 1994.

[8]. Phadke M. S., Quality engineering using robust design, Englewood Cliffs, New Jersey: Prentice Hal, 1989.

[9]. Samoila C., Ionescu M.S., Drugă L., Tehnologii şi utilaje moderne de incălzire, București: Editura Tehnică, 1986.

[10]. Vermeşan G., Tratamente termice, Indrumător, Editura Dacia: Cluj Napoca, 1987.

[11]. Popescu N., Vitănescu C., Tehnologia tratamentelor termice, București: Editura Tehnică, 1974.

[12]. Mihăilă C., Procese termodinamice în sisteme gaz-solid și aplicaţiile lor in industrie, Bucureşti: Editura Tehnică, 1983.

[13]. Kunii D., Levenspiel O., Fluidization engineering, New York, John Wiley \& Sons, Inc., 1969.

[14]. Baskakov A. P., Nagrev I ohlajdenie metallov v kipiasciem sloe, Moscova: Metalurghia, 1974.

[15]. Ivanuş Gh., Todea I., Pop Al., Nicola S., Damian Gh., Ingineria fluidizării, Bucureşti, Editura Tehnică, 1996.

[16]. Esayan L., Esayan M., Fluidizarea, Editura Tehnică, Bucureşti, 1959.

[17]. Samoila C. Drugă, Stan I., Cuptoare şi instalaţii de incălzire, Bucureşti, Editura Didactică şi Pedagogică, 1983.

[18]. Bâclea Adolf, Dobrovici Sorin, Quality Engineering Applications on the Nitriding Steel in Fluidized Bed, The Annals of "Dunarea de Jos" University of Galati, Fascicle IX, Metallurgy and Materials Science, p. 81-87, ISSN1453-083X, 2002. 